\title{
BRIDELIA SCANDENS: REVIEW ON TRADITIONAL USES AND PHARMACOLOGICAL ASPECTS
}

\author{
Preetham. $\mathbf{J}^{1}$, Kiran. $\mathrm{S}^{2}$, Sharath.R ${ }^{3}$, Sujan Ganapathy P.S ${ }^{4}$, Sushma S.Murthy ${ }^{5}$ \\ ${ }^{I}$ Department of Biotechnology, Dayananda Sagar College of Engineering, Kumaraswamy Layout Bangalore -560078, \\ Karnataka, India. \\ ${ }^{2}$ Department of Biotechnology, Dayananda Sagar College of Engineering, Kumaraswamy Layout Bangalore -560078, \\ Karnataka, India. \\ ${ }^{3}$ Department of Biotechnology, M.S. Ramaiah institute of Technology, MSRIT Post Bangalore, Karnataka, India. \\ ${ }^{4}$ Research and Development Centre, Olive Life sciences Pvt. Ltd., Nelamangala, Bangalore- 56212 Karnataka, India. \\ ${ }^{3}$ Department of Biotechnology, M.S. Ramaiah institute of Technology, MSRIT Post Bangalore, Karnataka, India.
}

\begin{abstract}
Plants are being used as a medicine to heal various disorders from the beginning of civilization. Bridelia scandens belonging to the family Euphorbiaceae is distributed in India and other regions in the world. Different parts of B.scandens are used traditionally in treatment of jaundice, malaria, herpes, oral problems, allergies, inflammation, scabies, and dermatitis and so on. B.scandens has been investigated by researchers for its biological activities and therapeutic potentials such as antidiabetic, antioxidant, antibacterial, hepatoprotective activity. However studies are yet to be carried out in order to prove the folklore usage of this plant. The present review focuses on folkloric uses, phytoconstituents, and pharmacological activities of the extracts of B.scandens.
\end{abstract}

Keywords: Bridelia scandens, Hepatoprotective, Antioxidant, Antidiabetic. $* * *$

\section{INTRODUCTION}

Medicinal plants are being used ever since from beginning of civilization to treat various illnesses. Till the industrial revolution herbal medicine was only known to mankind in the name of therapy $[1,2]$. However, today there is colossal storage of knowledge concerning to therapeutic usage of these medicinal plants [3].India is known for its wealthiest resource of medicinal flora, used traditionally from last two millennia. Because of its extensive variation in meteorology, topography and climate, enormity of flourishing flora is raising anywhere else on the surface of earth [2]Research on plant based curing for different conditions was strengthened in the $20^{\text {th }}$ century $[1,4]$ Investigation for new drugs or phytotherapy is emphasized further apart from identifying and documenting[5,6]. Based on the available scientific literature from past decades says that use of herbal medicine as an alternative or complementary therapy is of great importance for well-being [7].

Bridelia scandens is a large woody evergreen climber or straggling shrub with pendent branches armed with large deflexed spines (Fig.1 A). Leaves elliptic -oblong or ovate $2.5-10 \times 1.2-5 \mathrm{~cm}$, subcoriaceous, glabrous above, pale pubescent beneath. Flowers are monoecious, greenishyellow, in small dense axillary clusters or long spikes, often subtended by stipular hairy obliquely tanceolate acute bracts (Fig.1 A, B). Calyx 5mm long, hairy, Segments are triangular-ovate, acute, connate at base, crenulated at apex. Staminal column is $3 \mathrm{~m}$ long, top anthers, styles with long slender arms. Drupes are 9mm long or more, ellipsoidoblong seated on the slightly enlarged calyx and is black juicy when ripened [8]. It is disturbed in India and Southeast Asia .In India it has spread throughout in the dense evergreen forests of Western Ghats [9].

\subsection{Traditional Claims}

Bark decoction of B.Scandens is used for cough, fever and asthma [11.12] and jaundice [13, 14].Decoction of wood of B.Scandens administered orally to treat malaria disease[15].Leaf extracts are used to treatment of jaundice $[12,16,17]$, allergy[18,19,12] inflammation, scabies, dermatitis[20] and anaemia due to pregnancy[12]. Leaf powder and warm leaf poultice are applied to white spots in the skin [12].Root extract along with the combination for other plant is used to treat herpes [21].Fruits are edible, yield a black coloring matter [22]. 


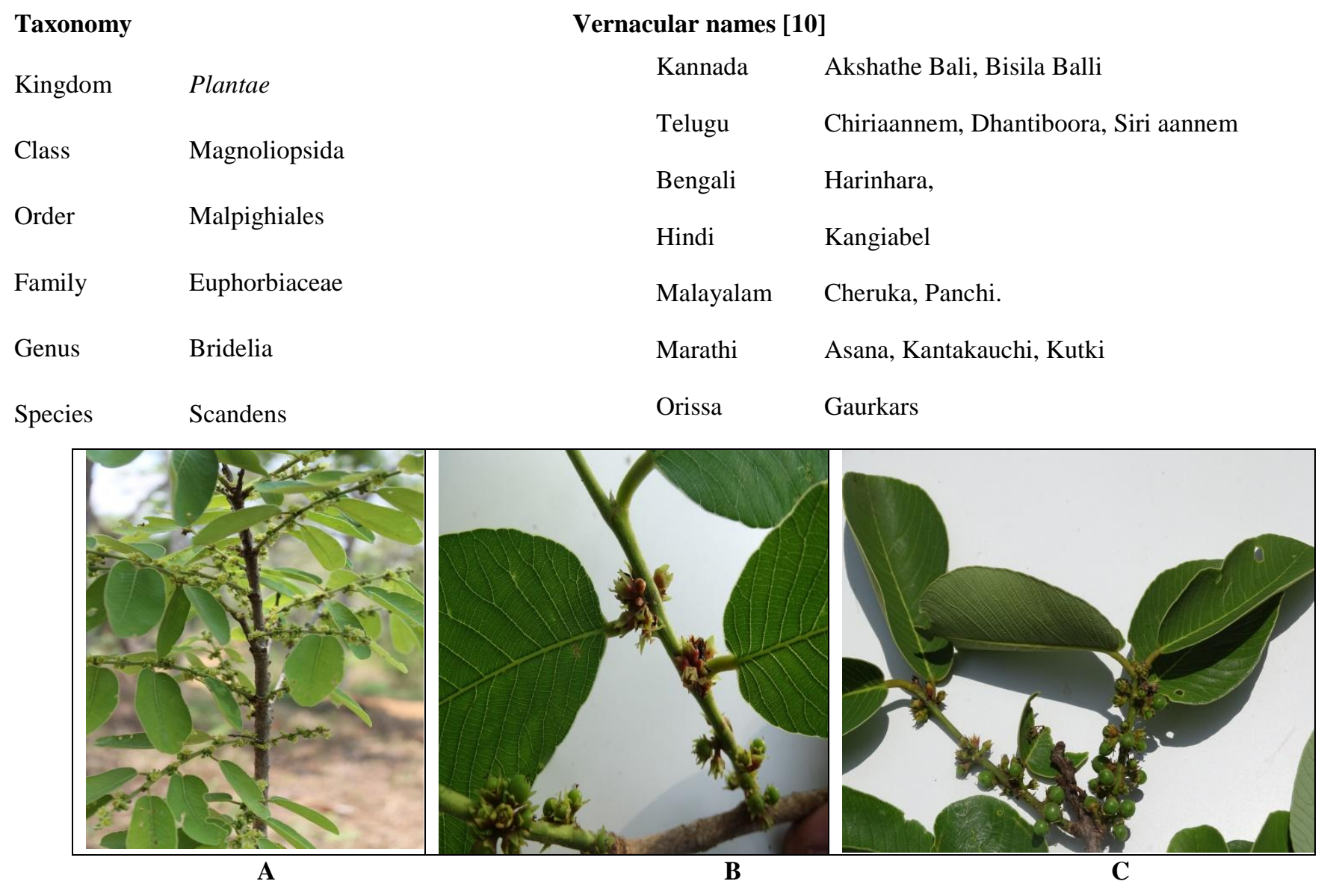

Fig .1 Bridelia scandens

\subsection{Chemical Constituents}

Tannins were isolated from the bark of B.scandens [23], fatty alcohol called bridely alcohol and phlobatannin was isolated from leaves [24], taraxenone and taraxenone was from roots [25] till date.

\subsection{Antimicrobial Activity}

Antimicrobial activity were screened for different extracts of stem bark and leaf of B.scandens against various gram positive and gram negative bacteria, wherein the methanolic extract exhibited the highest zone of inhibiton of $23 \mathrm{~mm}$ against Staphylococcus aureus and lowest of $11.9 \mathrm{~mm}$. Antifungal screening of B.scandens against Aspergillus niger, Candida albicans, and Saccharomyces cerevisiae for various extracts ranges between 9 to $17.5 \mathrm{mg}$ [26].Iinhibitory effect of the leaves and fruit extracts of B.scandens on Staphylococcus aureus, Escherichia coli, Pseudomonas aeruginosa, Salmonella typhi, Shigella flexneri Vibrio cholera was studied by time kill assay and MIC was also evaluated. This illustrates that B.scandens can be used as source of antimicrobial agent against pathogenic bacteria. [27].

\subsection{Antioxidant Activity}

In vitro antioxidant potential of various extracts of whole plant of B. scandens was determined by different models hydroxyl radical scavenging, nitric oxide, and total phenol content. Whereas $\mathrm{IC}_{50}$ value for methanolic extract found to be more effective $(50 \mu \mathrm{g} / \mathrm{ml})$ in hydroxyl radical and nitric oxide $(130 \mu \mathrm{g} / \mathrm{ml})$ scavenging than petroleum ether and ethyl acetate extracts. Compare to all extracts and standard, methanolic extract showed better results in scavenging activity. It also showed considerable amount of phenolic content $(4.80 \pm 0.039 \mathrm{mg} / \mathrm{g}$ of catechol), which attributes for its antioxidant activity [9].

\subsection{Antihepatotoxic Activity}

In vivo antioxidant activity and lipid peroxidation was evaluated for various solvent extracts $(300 \mathrm{mg} / \mathrm{kg}$ body weight) of whole plant of Bridelia Scandens in $\mathrm{CCl}_{4}$ induced rats. Methanolic extract of $B$. scandens in $\mathrm{CCl}_{4}$ treated rats reduced the concentration of TBRAS, when compared with $\mathrm{CCl}_{4}$ treated rats. Administration of methanolic extract of $B$. scandens in $\mathrm{CCl}_{4}$ treated rats showed significant $(\mathrm{p}<0.001)$ increase in the levels of antioxidant enzymes like superoxide dismutase(SOD) ,Catalase(CAT), Glutathione peroxidase, Glutathione reductase and reduced the level of nonenzymatic antioxidant glutathione. Methanolic extract of B.scandens showed a significant antioxidant property, helpful in preventing various oxidative stresses [28]. 


\subsection{Antidiabetic Activity}

Alcoholic leaf extract of B.scandens (200 \& 400mg/kg body weight) was evaluated for its antidiabetic property in streptzotin induced rats. Blood glucose level was determined by GOD-POD kit method and was compared with the oral dose of $0.6 \mathrm{mg} / \mathrm{kg}$ Glibenclamide. Alcoholic extract significantly lowered blood glucose in dose dependent manner compared to standard drug glibenclamide [29].

\section{CONCLUSION}

Bridelia scandens is used by few tribes of Western Ghats to cure many ailments, which forms a basis to carry out the research activity. Different parts of $B$. scandens are being used in the traditional system of medicine to cure various illness of human kind. Researchers have confirmed it for few pharmacological abilities of B.scandens and proved to be safe. In future attempt has to be done to prove all the traditional potentials of B.scandens

\section{REFERENCES}

[1] Benziegu IFF, Wachtel GS (2011) Herbal Medicine: Biomolecular and Clinical Aspects. $2^{\text {nd }}$ ed. Boca Raton (FL), CRC Press.

[2] Sayed nudrat zawar (2011) Medicinal plants, Holistic Approaches. New India publishing Agency.

[3] Kokate CK, Purohit AP, Gokhale SB (2008) Pharmacognsy .19th edt, Nirali prakashan Publications.

[4] Bone K, Mill S (2013) Principles and practice of phytotherapy.2nd edt, Elsevier Health Sciences.

[5] Harvey AL (1999) Natural products in drug discovery. Drug discovery today, 13:894-901.

[6] Heinrich $M$ and Gibbons S (2001) Ethno pharmacology in drug discovery: an analysis of it role and potential contribution. Journal of Pharmacy and Pharmacology 53, 425-432.

[7] Rates SMK (2001) Plants as source of drugs. Toxicon 39, 603-613.

[8] Pullaiah T (2006) Encyclopaedia of world medicinal plants. Regency Publications. Vol 1.

[9] Senthil KD, Kottai MA, and Satheesh KD, Manavalan R (2010) In vitro antioxidant potential of various extracts of whole plant of Bridelia scandens (Roxb) wild. Der Pharma Chemica; 2(2): 195-201.

[10] Gupta AK, Madhu S, Neeraj tendon (2004). Reviews on Indian Medicinal Plants Indian Council of medicinal Research New Delhi; 4.

[11] Raj Kumar MH and Rajanna MD (2011) Ex-situ conservation of climbing plants at university of agricultural sciences, Bangalore, Karnataka. Recent Research in Science and Technology, 3(4): 18-20.

[12] Http://www.ebbd.info/brideliastipularis.,Bangladesh.

[13] Maji Jose, Bhagya B, Manjula shantaram (2011) Ethno medicinal herbs used in oral health and hygiene in coastal dakshina Kannada. Journal of Oral health community dentistry; 5(3):119-123.
[14] Lalitha Rani S, Kalpana Devi V, Tresina Soris P et al (2011) Ethno medicinal plants used by Kanikkars of Agasthiarmalai Biosphere Reserve Western Ghats. Journal of Ecobiotechnology 3(7): 16-25.

[15] Oratai N, Patcharin S, Kornkanok Y, Narumon S (2012) A survey of medicinal plants in mangrove and beach forests from sating Phra Peninsula, Songkhla Province, Thailand. Journal of Medicinal Plants Research 6(12): 2421-2437.

[16] Sankaranarayanan AS (1988) Folk-lore medicines for jaundice from Coimbatore and Palghath districts of Tamilnadu and Kerala, India. Ancient Science of Life 7(3\&4):175-179.

[17] Rama Shankar, Rawat MS, Deb S, Sharma $\mathrm{BK}(2012)$ Jaundice and its traditional cure in Aruncchal Pradesh. Journal of pharmaceutical and scientific innovation, 1(3):93-97.

[18] Tuhin K, Reatul K, Sharmin RC, Rebecca B (2012) Ethno medical Studies of Chakma Communities of Chittagong Hill Tracts. Bangladesh. Bangladesh Pharmaceutical Journal 15(1): 59-6.

[19] Md Atiquar Rahman. Indigenous knowledge of herbal treatment of skin diseases by tribal communities of the hill tracts districts of Bangladesh (2010).Ethanobotany and medicinal plants Bangladesh Journal. Botany 39(2): 169-177.

[20] Md. Shahadat H, Prozzal R, Syeda S et al (2012) Ethnomedicinal knowledge among the Tonchongya tribal community of Roangchaari Upazila of Bandarban district, Bangladesh. American-Eurasian Journal of Sustainable Agriculture 6(4): 349-359.

[21] Bhandary M J, Chandrashekar K R (2011) Herbal therapy for herpes in the ethno- medicine of coastal Karnataka. Indian journal of traditional knowledge 10(3):528-532.

[22] Narayan Das, Praja pati, Kumar U (2003) Agro's dictionary of medicinal Plants. Agrobios publication.

[23] Ngueyema TA, Brusotti G, Caccialanzaa P, Vita Finzi (2009) the genus Bridelia: A phytochemical and ethnopharmacological review. Journal of Ethnopharmacology 124 339-349.

[24] Sengupta P, Ghosh B.N, (1963) Chemical investigation of the bark of Bridelia stipularis. Indian Journal of Chemistry 40, 247-24

[25] Desai HK, Gawad, DH, Govindachari TR, (1976). Chemical investigation of some Indian plants part IX. Indian Journal of Chemistry 14b, 473-475.

[26] Adeeba Anjum, Mohammad RH, Mohammad SR et al (2011).In vitro antibacterial, antifungal and cytotoxic activity of three Bangladeshi Bridelia species. International Research of Pharmacy and Pharmacology; 1(7):149-154.

[27] Kotigadde S, Jose S, Zachariah A et al (2005). Antibacterial activity of Bridelia scandens. Journal of Community Disease 37(2):135-7.

[28] Senthilkumar D, Muthu A. Kottai muthu, Manavalan R (2012) Lipid Peroxidation and in vivo antioxidant effect of various extracts of whole plant of Bridelia scandens in $\mathrm{CCl} 4$ Induced Hepatotoxicity Rats. Asian Journal of Chemistry 24 (5):2017. 
[29] Gomathi V, Jaykar B (2015) Antidiabetic activity of ethanolic leaf extract of Bridelia scandens in streptozotocin induced diabetic rats. Journal of Pharmacy Research 9(3): 190-193. 